\title{
Organization of the Internal State Financial Control in Conditions of Russian Economy Digitalization
}

\author{
Simko N.N. ${ }^{1, *}$ Shatkovskaya E.G. ${ }^{2}$ Piontkevich N.S. ${ }^{3}$ \\ ${ }^{1}$ Federal Treasury Department for the Sverdlovsk region, Yekaterinburg, Russia \\ ${ }^{2}$ Ural State Mining University (URSMU), Yekaterinburg, Russia \\ ${ }^{3}$ Ural state university of Economics (USUE), Yekaterinburg, Russia \\ *Corresponding author. Email: simko.nat@mail.ru
}

\begin{abstract}
Russian economic policy is aimed at the preservation and consolidation of the country's positions of internal and external markets. For these purposes, information technologies and digitalization methods are being actively implemented in the Russian economy in terms of state program implementation. This allows providing a complex assessment of the social and economic efficiency of the state economic policy implementation. Digitalization of the state economy sector, building interdepartmental interaction between federal executive authorities, interaction based on agreements with business entities with various forms of property is designated to consolidate the national economy sustainability. The need arises to develop and to establish new rules and conditions of carrying out state financial control, including the internal financial control, carried out by Federal Treasury, for providing the safety of the finance system, spending budget funds, and increasing the management decision making efficiency. The wide official material on the issues of the digital transformation of federal executive authorities of the Russian Federation was processed in the study, the control method in the form of remote finance monitoring was offered, prospects of development of the modern system of internal state financial control with the use of the risk-oriented approach were considered,
\end{abstract}

Keywords: control, financial control, internal state financial control, finance and budget field, Federal

Treasury, economy, digitalization

\section{INTRODUCTION}

Considering the social and economic system in terms of the state financial resources and economic policy entities that receive these resources in the form of budget funds, interbudget transfers (subsidies, subventions), credits and other forms of the state aid, it should be understood that the allocation of the state financial resources provides for the conduct of the state financial control over their use.

In accordance with the Budget Code of the RF, the state (municipal) financial control is carried out with the purposes to provide enforcement of legislation in the field of regulating budget jural relations, is the control activity of Federal Treasury, state (municipal) financial control authorities [1]. Today, powers for carrying out internal financial control on the federal level belong to Federal Treasury and its territorial bodies (e.g., on the territory of the Sverdlovsk Region of the Russian Federation - Federal Treasury Administration in Sverdlovsk Region $[1 ; 2 ; 3 ; 4$; 5].

Before 2016, it was a task of Federal Service for Financial and Budgetary Supervision and its territorial bodies, that was eliminated with the purpose of improvement of the state control and supervision in the finance and budget field, optimization of the federal executive authorities [6].

In its actions, Federal Service for Financial and Budgetary Supervision was governed by legislative and regulatory acts of the federal level $[7 ; 8 ; 9 ; 10 ; 11]$ and on a regional level, represented by territorial bodies of Federal Service for Financial and Budgetary Supervision (Territorial Administration Office of Federal Service for Financial and Budgetary Supervision of Sverdlovsk Region) [12].

One of reasons for reforming Federal Service for Financial and Budgetary Supervision was the need to use Federal Treasury internal information resources, connected with the receipt information on the control object financing and the use of funds, allocated to this object, from Federal Treasury programs.

Open access to these programs was a strong foundation for organization, planning, and implementation of control events in finance and budget field.

Earlier, information was provided in the simplified form according to inquiries on paper and electronic carriers. Delegation of powers of internal financial control to Federal Treasury enabled the development of an internal state financial control system by its digitalization in connection with the transformation of the state sector itself, building interdepartmental interaction between federal executive authorities. 
In foreign counties, a similar experience was observed in China where the treasury functions were centralized with the purpose to improve the state financial control [33, p. 263].

Today, digital platforms are the common form of mediation and infrastructure in the society [32, p. 562]. Ministry of Digital Development, Communication and Mass Communication of the Russian Federation by the instruction of the Government of the Russian Federation [13] developed requirements to candidates for the position of Deputy Director of the federal executive authority, responsible for digital transformation and methodical recommendations for testing their managerial skills [14]. Tasks were developed, and the expected results of fulfilling the national program "Digital Economy" and federal projects, included in it, were determined $[15 ; 16]$.

Federal Treasury, together with the Department of Architecture Development and Informatization Coordination of Ministry of Communications of Russia, Department of Digital Transformation of Accounts Chamber of the Russian Federation, Ministry of health, took part in the discussion "Digital Economy HR", where the possibilities of attracting and keeping the best HR for the digital transformation of state sectors, the required competences for officials dealing with digital transformation projects, were discussed [17].

\section{RESEARCH METHODOLOGY}

The paper uses such basic investigation methods as the scientific abstraction method, logic thinking method, dialectic cognition method, statistical method, comparative analysis method, and observation method.

The study information base were materials of the Territorial Administration Office of Federal Service for Financial and Budgetary Supervision of Sverdlovsk Region, official statistical information of the Territorial Administration Office of Federal Service for Financial and Budgetary Supervision, published within its validity period [18], Public reports on the results of activity of Federal Treasury Administration in Sverdlovsk Region for 2017-2019 [19; $20 ; 21]$, the information into which was entered based on the data formed in the Computer-aided planning system application programs (CAPS AP) $[22 ; 23]$.

Before 2018, in accordance with the c current legislation [24], in Federal Treasury at planning and implementation of control events, distributing the results of their conduct and forming reports, the applied system program "Automated system of planning control and supervisory activity of Federal Service for Financial and Budgetary Supervision in modules performed (ASA ASP Revisor) was used which, prior to the transfer of powers for the implementation of internal of the state financial control, was also used by the Federal Service for Financial and Budgetary Supervision" [26, p. 35].

\section{RESEARCH RESULTS}

The national economy development level is to the great extent substantiated by the degree of the competitive ability of various forms of ownership, and professional level of federal executive authorities, incuding the federal executive authority, performing the function of internal of the state control authority.

The study result is the conducted comparative analysis of indicators of activity of control and supervision in the finance and budget field for 2010-2012 and for 20172019 (Table 1). The analysis showed that in modern conditions of Russian economy digitalization, nature and degree of violations revealed changed, and the need emerged to develop an internal state financial control system with the use of the risk-oriented approach. There need exists to create the legal entity's "Personal Account" on the Federal Treasury portal with the purpose to of monitoring and analyzing information in Federal Treasury information systems, and for the purposes of analysis of the remaining public open information published online, systematized by separate directions and set by the risk intensity selection criteria: "wide implementation of information technologies into modern activity creates all possibilities for the transfer to the new control paradigm based on the data of information systems and risk management systems" [30, p. 48].

In modern conditions, the efficient state management provides for the timely monitoring of global challenges and forming the pioneering methods of impact on them [29, p. 6].

The conducted analysis demonstrated hat the dynamics of indicators was various, but the productivity indicators decrease is observed. Accordingly, the existing approach to the disclosure of violations should be reconsidered.

For example, the mechanism of revealing violations in the finance and budget field is based on methods of carrying out the state (municipal) financial control, such as check, revision, and examination [1]. According to practice, control measures usually have the form of the on-site check, and actually, the most issues can be considered with the help of cameralistic check (e.g., when checking the reasonability of purchases in the part of following the norming rules in the field of purchases and in the part of determination and substantiation of the initial (maximal) contractual price, the initial sum of the product units, at checking the completeness and timeliness of submitting the accounting (budgetary) reporting, timeliness of submitting the data of obligations, being taken and already taken, etc. [28, p. 215216].

One of the innovative solutions can become implementing technologies of remote control based on remote finance monitoring into control and supervisory activity in the finance and budget sphere.

For example, in control and supervisory activity of internal financial control authorities, one can be oriented by the position of Alyoshin O.V. about the reasonability of transfer to new instruments of implementing control measures in control and supervisory activity, the readiness of information sources about the production safety state, and 
methods of their processing to transfer to the digital format. The need to implement the information system under the conditional name "E-supervisor" was declared. In this case, all the mandatory documentation kept by the organization operating the hazardous production facility can be transferred from paper form to electronic form and filled out directly in the each organization's personal account in our information system: "the program will automatically compare all the documents submitted with templates, and will display information on possible errors and violations. Accordingly, the operating company will receive the opportunity to carry out real-time checks and to correct violations without waiting for the supervisor's arrival..." [34].

According to the specialists' assessment, implementation of the remote monitoring system is possible provided that the following conditions are fulfilled: first, creating the necessary regulatory base...; second, providing the supervisory service employees with instruments for digital data operation. For this purpose, it is planned to entrust the Ministry of Finance of Russia, in the preparation of a draft amendment to the federal budget for 2020 and the scheduled period of 2021-2022, to provide additional budget assignations for modernization of information and communication infrastructure of Rostekhnadzor in the amount, coordinated by the Ministry of Digital Development" [25].

Therefore, authors, governed by practical experience in the Russian finance and budget field, suggest reconsidering the legally fixed methods of the state (municipal) financial control, and provide for remote finance monitoring, based on the warning on preventing violations and reduced to notification of the control object about the inadmissibility of the certain actions and warning about the possibility of the appearance of administrative responsibility for violations in finance and budget field, as an innovative method of carrying out control events in the finance and budget field. If the employee received a remote notification about the inadmissibility of committing the administration offense but still did not fulfill the requirements of the statefederal executive authorities, penalty sanctions arise in this case.

\section{DISCUSSION}

The need for changing approaches to the implementation of the internal state financial control of the Federal Treasury in conditions of the Russian economy digitalization in 20182019 was actively discussed at international and all-Russian Research-to-Practice Conferences.

On March 18, 2020, the extended meeting of the Federal Treasury panel was held in Federal Treasury. The event participants were: Minister of Finance of Russia AntonSilyanov, Deputy Minister of Finance of Russia Tatiana Nesterenko, Vice Chairman of the Federation Council of the Russian Federation Nikolay Zhuravlev, Director of Federal Service for Financial Monitoring Yuriy Chikhanchin, federal authorities and expert community representatives.

Managers and employees of the Federal Treasury territorial authorities, representatives of financial authorities of the subjects of the Russian Federation and municipalities took part in the event in the video conference format. In his speech, Roman Artiukhin summed up the activity for 2019 and told about the main directions of the Federal Treasury development for 2020 in terms of digitalization, accounting centralization, e-document circulation development and refusal from paper carriers, and of interaction with Rosfinmonitoring (Federal Service for Financial Monitoring) [31].

Table 1 Comparative analysis of activity indicators for control and supervision in finance and budget field for 2010-2012 and for 2017-2019 (on the example of territorial executive authorities, that were performing the function of the state internal financial control authority in the Russian Federation on the territory of Sverdlovsk Region for the period from 2004 to 2019 on the federal level)

\begin{tabular}{|c|c|c|c|c|c|c|c|}
\hline \multirow[t]{2}{*}{ Indicators } & \multicolumn{3}{|c|}{$\begin{array}{l}\text { Territorial Administration Office of Federal } \\
\text { Service for Financial and Budgetary } \\
\text { Supervision of Sverdlovsk Region }\end{array}$} & \multicolumn{3}{|c|}{$\begin{array}{l}\text { Federal Treasury Administration } \\
\text { in Sverdlovsk Region }\end{array}$} & \multirow{2}{*}{$\begin{array}{l}\text { Compariso } \\
\text { n of indices } \\
\text { for } 2012 \\
\text { and } 2019 \\
(+;-)\end{array}$} \\
\hline & 2010 & 2011 & 2012 & 2017 & 2018 & 2019 & \\
\hline $\begin{array}{l}\text { 1. The total number of } \\
\text { organizations that are federal } \\
\text { money recipients, included in } \\
\text { the following Consolidated } \\
\text { List of chief budgetary units, } \\
\text { budgetary units and budget- } \\
\text { holders (hereinafter referred } \\
\text { to as CLBUBH), carrying out } \\
\text { their activity on the territory } \\
\text { of Sverdlovsk Region, units. }\end{array}$ & 878 & 681 & 524 & 1,519 & 1,870 & 1,976 & $\begin{array}{l}+1,452 \\
(277 \%)\end{array}$ \\
\hline $\begin{array}{l}\text { 2. The total number of } \\
\text { checked budget-holding } \\
\text { organizations (included in } \\
\text { CLBUBH), carrying out their } \\
\text { activity on the territory of } \\
\text { Sverdlovsk Region, units. }\end{array}$ & $\begin{array}{l}195 \\
(22.21 \% \text { from } \\
\text { the total } \\
\text { amount of } \\
\text { recipients) }\end{array}$ & $\begin{array}{l}179 \\
\text { (26.3\% from } \\
\text { the total } \\
\text { amount of } \\
\text { recipients) }\end{array}$ & $\begin{array}{l}133 \\
\text { (25.4\% from } \\
\text { the total } \\
\text { amount of } \\
\text { recipients) }\end{array}$ & $\begin{array}{l}45 \\
(2.41 \% \\
\text { from the } \\
\text { total } \\
\text { amount of } \\
\text { recipients })\end{array}$ & $\begin{array}{l}103 \\
\text { (5.51\% from } \\
\text { the total } \\
\text { amount of } \\
\text { recipients) }\end{array}$ & $\begin{array}{l}137 \\
(6.93 \% \\
\text { from the } \\
\text { total } \\
\text { amount of } \\
\text { recipients })\end{array}$ & $\begin{array}{l}+4 \\
(3 \%)\end{array}$ \\
\hline
\end{tabular}




\begin{tabular}{|c|c|c|c|c|c|c|c|}
\hline $\begin{array}{l}\text { 3. Number of control } \\
\text { measures carried out in the } \\
\text { finance and budget field } \\
\text { (revisions, examinations and } \\
\text { checks), units. }\end{array}$ & $\begin{array}{l}354, \\
\text { of them, } \\
\text { checks } 354\end{array}$ & $\begin{array}{l}297, \\
\text { of them, } \\
\text { checks } 297\end{array}$ & $\begin{array}{l}256, \\
\text { of them, } \\
\text { checks } 256\end{array}$ & $\begin{array}{l}144, \\
\text { of them, } \\
\text { checks } 127\end{array}$ & $\begin{array}{l}159 \\
\text { of them, } \\
\text { checks } 129\end{array}$ & $\begin{array}{l}157, \\
\text { of them, } \\
\text { checks } 140\end{array}$ & $\begin{array}{l}-99 \\
(38 \%)\end{array}$ \\
\hline $\begin{array}{l}\text { 4. Amount of funds checked, } \\
\text { total, ths. RUB }\end{array}$ & $\begin{array}{l}168,410,717.4 \\
59\end{array}$ & $\begin{array}{l}60,383,828.78 \\
5\end{array}$ & $\begin{array}{l}87,596,703.09 \\
8\end{array}$ & $\begin{array}{l}49,486,141 \\
185\end{array}$ & $\begin{array}{l}147,506,242.9 \\
08\end{array}$ & $\begin{array}{l}57,588,277 . \\
084\end{array}$ & $\begin{array}{l}- \\
30,008,429 . \\
01 \\
(38 \%)\end{array}$ \\
\hline $\begin{array}{l}\text { of them: from federal budget, } \\
\text { ths. RUB }\end{array}$ & $\begin{array}{l}38,967,366.74 \\
3\end{array}$ & $\begin{array}{l}33,479,462.80 \\
5\end{array}$ & $\begin{array}{l}44,498,797.40 \\
7\end{array}$ & $\begin{array}{l}6,241,726.9 \\
63\end{array}$ & $\begin{array}{l}63,723,153.14 \\
0\end{array}$ & $\begin{array}{l}33,241,358 \\
856\end{array}$ & $\begin{array}{l}- \\
11,257,438 . \\
55 \\
(25 \%) \\
\end{array}$ \\
\hline $\begin{array}{l}\text { 5. Violations detected in } \\
\text { finance and budget field } \\
\text { based on the results of contol } \\
\text { measures performed, ths. } \\
\text { RUB }\end{array}$ & $\begin{array}{l}13,433,880.22 \\
6\end{array}$ & $2,911,949.031$ & $7,488,414.833$ & $\begin{array}{l}5,727,669.7 \\
75\end{array}$ & $8,834,563.611$ & $\begin{array}{l}4,196,618.7 \\
80\end{array}$ & $\begin{array}{l}-3,291,796 \\
(43 \%)\end{array}$ \\
\hline $\begin{array}{l}\text { including the use of federal } \\
\text { budget funds }\end{array}$ & $\begin{array}{l}12,098,475.86 \\
3\end{array}$ & $2,510,826.593$ & $6,349,695.600$ & $\begin{array}{l}1,101,645.2 \\
94\end{array}$ & $7,945,446.942$ & $\begin{array}{l}3,079,559.7 \\
21 \\
\end{array}$ & \\
\hline $\begin{array}{l}\text { 5.1. Inappropriate } \\
\text { expenditures, ths. RUB }\end{array}$ & $\begin{array}{l}32,285 \\
794\end{array}$ & $\begin{array}{l}18,401 \\
914\end{array}$ & $\begin{array}{l}4,407 \\
528\end{array}$ & $\begin{array}{l}2,497 \\
422\end{array}$ & 0.000 & 193.230 & $\begin{array}{l}-4,214.298 \\
(95.616 \%)\end{array}$ \\
\hline $\begin{array}{l}\text { 5.2. Inefficient use of } \\
\text { material resources and } \\
\text { money funds, ths. RUB }\end{array}$ & $58,036.379$ & $31,400.850$ & $666,032.266$ & $40,083.291$ & $23,501.500$ & $2,504.527$ & $\begin{array}{l}- \\
663,527.73 \\
9 \\
(99.623 \%)\end{array}$ \\
\hline $\begin{array}{l}\text { 5.3. Divergence of the actual } \\
\text { availability of money funds } \\
\text { and material values with the } \\
\text { accounting data (shortage of } \\
\text { money funds and material } \\
\text { resources, exceed of money } \\
\text { funds and material } \\
\text { resources), ths. RUB }\end{array}$ & 500.255 & $6,791.818$ & $3,207.429$ & $\begin{array}{l}3,752,879.3 \\
94\end{array}$ & $5,110.26$ & 39.377 & $\begin{array}{l}-3,167.659 \\
(98.772 \%)\end{array}$ \\
\hline $\begin{array}{l}5.4 \text { Shortfall of payment into } \\
\text { the budget, ths. RUB }\end{array}$ & $13,166.137$ & $7,983.813$ & $3,374.634$ & 0 & 0 & 0 & $\begin{array}{l}-3,374.639 \\
(100 \%)\end{array}$ \\
\hline $\begin{array}{l}\text { 5.5. Breach of order of funds } \\
\text { use (illegal expenditures of } \\
\text { funds and material } \\
\text { resources), ths. RUB }\end{array}$ & $516,157.812$ & $168,762.081$ & $508,815.673$ & $4,119.178$ & $3,351,240.480$ & $\begin{array}{l}445,024.58 \\
7\end{array}$ & $\begin{array}{l}- \\
63,791.086 \\
(12.537 \%)\end{array}$ \\
\hline $\begin{array}{l}\text { 5.6. Other violations } \\
\text { (maintenance of accounting } \\
\text { records and accounting } \\
\text { compilation, non-inclusion } \\
\text { into the federal property } \\
\text { register of data about real } \\
\text { estate or its disposal, } \\
\text { undertaking obligations at the } \\
\text { absence of expenditure } \\
\text { credits of budget obligations, } \\
\text { violations in the field of } \\
\text { procurement), ths. RUB }\end{array}$ & $\begin{array}{l}12,809,733.84 \\
9\end{array}$ & $2,678,608.555$ & $6,302,877.303$ & $\begin{array}{l}1,928,090.4 \\
90\end{array}$ & $5,454,711.371$ & $\begin{array}{l}3,748,857.0 \\
59\end{array}$ & $\begin{array}{l}- \\
2,554,020.2 \\
44 \\
(40.521 \%)\end{array}$ \\
\hline $\begin{array}{l}\text { 6. The number of penalties } \\
\text { imposed, based on the results } \\
\text { of control measures } \\
\text { conducted in the current year, } \\
\text { ths. RUB }\end{array}$ & 159 & 64 & 40 & 461.443 & 371.000 & 320.805 & $\begin{array}{l}+280.805 \\
(702.012 \%)\end{array}$ \\
\hline $\begin{array}{l}\text { 7. The total amount of } \\
\text { penalties paid, based on the } \\
\text { results of control measures } \\
\text { conducted, ths. RUB }\end{array}$ & 159 & 64 & 40 & 396.703 & 536.00 & 150.52 & $\begin{array}{l}+110.52 \\
(276.30 \%)\end{array}$ \\
\hline $\begin{array}{l}\text { 8. The total amount of funds } \\
\text { returned based on the results } \\
\text { of control measures } \\
\text { conducted and performed } \\
\text { submissions and } \\
\text { prescriptions in finance and } \\
\text { budget field, ths. RUB }\end{array}$ & $3,980,780.066$ & $1,913,903,398$ & $6,155,615.654$ & $\begin{array}{l}530,639.21 \\
5\end{array}$ & $219,645.553$ & $\begin{array}{l}294,805.16 \\
7\end{array}$ & $\begin{array}{l}- \\
5,860,810.4 \\
87 \\
(95.210 \%)\end{array}$ \\
\hline
\end{tabular}




\begin{tabular}{|l|l|l|l|l|l|l|l|}
\hline $\begin{array}{l}\text { 9. Actual total number of the } \\
\text { Administration employees, } \\
\text { prs. }\end{array}$ & 144 & 131 & 120 & 480 & 478 & 501 & $\begin{array}{l}+381 \\
(95.825 \%)\end{array}$ \\
\hline $\begin{array}{l}\text { of them: federal civil } \\
\text { servants who participated in } \\
\text { the conduct of control } \\
\text { measures, prs. }\end{array}$ & 75 & 62 & 51 & 50 & 54 & 54 & +3 \\
\hline
\end{tabular}

\section{CONCLUSIONS}

Today, it is required to provide transparence and availability of the state cash flows, to create the efficient state control system, in accordance with which Federal Treasury (through its territorial authorities, making them pilots of the separate projects), constantly improves them, which will allow providing the implementation of the basic state finance management principles.

The probability of the further use of the experience of foreign countries in the performance of control in finance and budget field is high. The experience of the state authority in financial control on the British financial market - Financial Conduct Authority, that initiated the creation of the "regulatory sandbox", is also interesting. "Regulatory platform" is a legal regime of testing new technologies in real time that provides for the release of the regulatory site member release from administrative responsibility and the application of supervisory measures.

In connection with this, the distributed database system ("blockchain" system) should be considered as a priority

technology of the budget funds monitoring system implementation, and it can act as a basis for creating the uniform centralized system of the state and municipal financial control in real time.

The "regulatory sandbox" practice can become a useful legal tool for assessing and managing regulatory risks, excluding bringing legal users of financial technologies to legal responsibility at the stage of testing in the real economy.

The wide use of automated monitoring systems in the field of improving finance operations will assist in resolving the conceptual issue of the existence of current control, so far from legally identified financial control methods.

The operation of automated systems will allow observing control objects (financial operations) during their existence for non-conformity to the preset criteria. For its conduct, qualified staff with the skills in modern competencies are required.

With the introduction of digital control methods, there will arise the risk of cyber threat in the finance and budget field - with the purpose of illegal possession of state property or confidential information in the field of financing from budget funds, etc.

With the purpose of implementing the national program "Digital Economy of the Russian Federation" [27], the Regulation on the system for managing the implementation of the national program "Digital Economy of the Russian Federation [26, p. 26-27] was approved.

On the whole, "creating a single information resource that will provide the integration of different state authorities with information systems will allow the considerable information interconnection simplification... between various control authorities, and move to planning and implementation of control measures applying the riskoriented approach. Control and supervisory authorities will have a possibility to transfer to the combine format of control and supervisory activity (cameralistic stage and the stage of checking on the control object site), to carry out the remote analysis of control objects and to coordinate their activity to avoid possible duplication. On-site checks on the control object will be carried out only in case of establishing risks of non-achieving control points of the national projects results in the course of cameralistic checks" [29, p.9].

Creation of the efficient digital instruments and the use of financial control methods based on them will allow providing the efficiency of control in the financial and budget field in the future.

\section{REFERENCES}

[1] "Byudzhetnyj kodeks Rossijskoj Federacii" ot 31.07.1998 N 145-FZ (red. ot 27.12.2019) [Elektronnyj resurs]/ Konsul'tantPlyus - Elektron.dan. - Rezhim dostupa:

http://www.consultant.ru/document/cons_doc_LAW_1 9702/ (data obrashcheniya: 26.03.2020).

[2] Postanovlenie Pravitel'stva RF ot 01.12.2004 N 703(red. ot 15.06.2019) "O Federal'nom kaznachejstve" [Elektronnyj resurs]/ Konsul'tantPlyus - Elektron.dan. Rezhim dostupa: http://www.consultant.ru/document/cons_doc_LAW_5 0565/ (data obrashcheniya: 26.03.2020).

[3] Postanovlenie Pravitel'stva RF ot 28.11.2013 N 1092 (red. ot 27.12.2019) "O poryadke osushchestvleniya Federal'nym kaznachejstvom polnomochij po kontrolyu v finansovo-byudzhetnoj sfere" (s izm. 03.01.2020) [Elektron. resurs]/ Konsul'tantPlyus - Elektron.dan. Rezhim dostupa: http://www.consultant.ru/document/cons_doc_LAW_1 55058/ (data obrashcheniya: 26.03.2020). 
osushchestvleniyu kontrolya i nadzora za soblyudeniem

[4] Prikaz Kaznachejstva Rossii ot 27.12.2013 N 316 (red. ot 10.06.2019) "Ob utverzhdenii polozhenij ob upravleniyah Federal'nogo kaznachejstva po sub"ektam Rossijskoj Federacii, a takzhe priznanii utrativshimi silu nekotoryh Prikazov Federal'nogo kaznachejstva") [Elektron. resurs]/ Konsul'tantPlyus -Rezhim dostupa: http://www.consultant.ru/document/cons_doc_LAW_2 24514/ (data obrashcheniya: 26.03.2020).

[5] Prikaz Kaznachejstva Rossii ot 01.03.2017 N 39 (red. ot 05.12.2018) "Ob utverzhdenii Standarta vnutrennej organizacii kontrol'nogo meropriyatiya "Obshchie trebovaniya $\mathrm{k}$ vnutrennej organizacii kontrol'nogo meropriyatiya" [Elektron. resurs]/ Konsul'tantPlyus Rezhim dostupa: http://www.consultant.ru/document/cons_doc_LAW_2 14274/ (data obrashcheniya: 26.03.2020).

[6] Ukaz Prezidenta RF ot 02.02.2016 No. 41(red. ot 15.05.2018) "O nekotoryh voprosah gosudarstvennogo kontrolya i nadzora $\mathrm{v}$ finansovo-byudzhetnoj sfere" [Elektronnyj resurs]/ Konsul'tantPlyus - Elektron.dan. Rezhim dostupa: http://www.consultant.ru/document/cons_doc_LAW_1 93262/ (data obrashcheniya: 26.03.2020).

[7] Postanovlenie Pravitel'stva RF ot 15.06.2004 N 278 (red. ot 02.11.2013) "Ob utverzhdenii Polozheniya o Federal'noj sluzhbe finansovo-byudzhetnogo nadzora" (utratilo silu s 15.02.2014) [Elektronnyj resurs]/ Konsul'tantPlyus _ $\quad$ Rezhim dostupa: http://www.consultant.ru/document/cons_doc_LAW_4 8057/ (data obrashcheniya: 26.03.2020).

[8] Postanovlenie Pravitel'stva RF ot 04.02.2014 N 77 (red. ot 25.12.2015) "O Federal'noj sluzhbe finansovobyudzhetnogo nadzora" [Elektron. resurs]/ Konsul'tantPlyus - Elektron.dan. - Rezhim dostupa: http://www.consultant.ru/document/cons_doc_LAW_1 58593/ (data obrashcheniya: 26.03.2020).

[9] Prikaz Minfina Rossii ot 20.03.2014 N 18n "Ob utverzhdenii Administrativnogo reglamenta ispolneniya Federal'noj sluzhboj finansovo-byudzhetnogo nadzora gosudarstvennoj funkcii po kontrolyu $\mathrm{v}$ finansovobyudzhetnoj sfere" (Zaregistrirovano v Minyuste Rossii 15.05.2014 N 32270) [Elektronnyj resurs]/ Konsul'tantPlyus - Elektron.dan. - Rezhim dostupa: http://www.consultant.ru/document/cons_doc_LAW_1 63325/ (data obrashcheniya: 26.03.2020).

[10] Prikaz Minfina RF ot 04.09.2007 N 75n (red. ot 04.10.2010) "Ob utverzhdenii Administrativnogo reglamenta ispolneniya Federal'noj sluzhboj finansovobyudzhetnogo nadzora gosudarstvennoj funkcii po zakonodatel'stva Rossijskoj Federacii pri ispol'zovanii sredstv federal'nogo byudzheta, sredstv gosudarstvennyh vnebyudzhetnyh fondov, a takzhe material'nyh cennostej, nahodyashchihsya v federal'noj sobstvennosti" (Zaregistrirovano v Minyuste RF 03.10.2007 N 10256) (utratil silu s 08.06.2014) [Elektronnyj resurs]/ Konsul'tantPlyus - Elektron.dan. Rezhim dostupa: http://www.consultant.ru/document/cons_doc_LAW_7 1723/ (data obrashcheniya: 26.03.2020).

[11] Postanovlenie Pravitel'stva RF ot 28.11.2013 N 1092 (red. ot 29.10.2014) "O poryadke osushchestvleniya Federal'noj sluzhboj finansovobyudzhetnogo nadzora polnomochij po kontrolyu $\mathrm{v}$ finansovo-byudzhetnoj sfere" (vmeste s "Pravilami osushchestvleniya Federal'noj sluzhboj finansovobyudzhetnogo nadzora polnomochij po kontrolyu $\mathrm{v}$ finansovo-byudzhetnoj sfere") [Elektronnyj resurs]/ Konsul'tantPlyus - Elektron.dan. - Rezhim dostupa: http://www.consultant.ru/cons/cgi/online.cgi?req=doc $\&$ $\mathrm{n}=170500 \&$ base $=$ LAW \& from $=341647$ -

0\&rnd $=0.07181249171151216 \# 006639033075478729$

(data obrashcheniya: 27.03.2020).

[12] Prikaz Minfina RF ot 11.07.2005 N 89n (red. ot 17.11.2010) "Ob utverzhdenii Polozheniya o territorial'nyh organah Federal'noj sluzhby finansovobyudzhetnogo nadzor" (Zaregistrirovano v Minyuste RF 05.08.2005 N 6888) (utratil silu s 08.01.2017) [Elektronnyj resurs]/ Konsul'tantPlyus - Elektron.dan. Rezhim dostupa: http://www.consultant.ru/document/cons_doc_LAW_5 4959/ (data obrashcheniya: 26.03.2020).

[13] Truman A.. Rukovoditeli 55 FOIV poluchat v podchinenie zamestitelya po voprosam cifrovizacii. 05.02.2020 [Elektronnyj resurs]/ - Elektron.dan. Rezhim dostupa: https://pravdaosro.ru/news/rukovoditeli-55-foivpoluchat-v-podchinen/ (data obrashcheniya 26.03.2020).

[14] Pis'mo Ministerstva cifrovogo razvitiya, svyazi i massovyh kommunikacij Rossijskoj Federacii "O napravlenii trebovanij $\mathrm{k}$ kandidatam na dolzhnost' zamestitelya rukovoditelya federal'nogo organa ispolnitel'noj vlasti, otvetstvennogo za cifrovuyu transformaciyu, i metodicheskih rekomendacij po provedeniyu testirovaniya ih upravlencheskih navykov [Elektron. resurs]/ -Rezhim dostupa: http://www.tadviser.ru/images/4/4f/05022020-2file.pdf (data obrashcheniya 26.03.2020). 
produkte ASP" (ne opublikovan, dovedyon do sotrudnikov Kaznachejstvom Rossii).

chinovnikov ministerstv. 13.03.2020 [Elektron. resurs]/ -Rezhim dostupa: https://www.cnews.ru/news/top/2020-0313_predstavlen_tsifrovoj_spetsnaz (data obrashcheniya 26.03.2020).

[16] Informaciya $s$ oficial'nogo sajta Pravitel'stva Rossijskoj Federacii. Vstrecha Mihaila Mishustina s zamestitelyami rukovoditelej federal'nyh organov ispolnitel'noj vlasti, otvetstvennymi za cifrovuyu transformaciyu, sostoyavshayasya 12.03 .2020 [Elektronnyj resurs] - Elektron.dan. - Rezhim dostupa: http://government.ru/news/39129/ (data obrashcheniya 26.03.2020).

[17] Informaciya $\mathrm{s}$ oficial'nogo sajta Federal'nogo kaznachejstva [Elektronnyj resurs]/ - Elektron.dan. Rezhim dostupa: https://www.roskazna.ru/novosti-isoobshheniya/novosti/1430900/ (data obrashcheniya 26.03.2020).

[18] Osnovnye pokazateli po itogam raboty Territorial'nogo upravleniya Federal'noj sluzhby finansovo-byudzhetnogo nadzora v Sverdlovskoj oblasti $\mathrm{v}$ sfere soblyudeniya byudzhetnogo zakonodatel'stva za 2010-2012 g. [Elektron. resurs]/ - Rezhim dostupa: http://www.r66.rosfinnadzor.ru (data obrashcheniya 26.08.2013).

[19] Publichnyj otchyot o rezul'tatah deyatel'nosti Upravleniya Federal'nogo kaznachejstva po Sverdlovskoj oblasti za 2017 g. [Elektronnyj resurs]/ Rezhim dostupa: https://sverdlovsk.roskazna.ru/upload/iblock/f2f/publich nyy-otchet_174_02_04_2018_ver1_.pdf (data obrashcheniya 25.03.2020).

[20] Publichnyj otchyot o rezul'tatah deyatel'nosti Upravleniya Federal'nogo kaznachejstva po Sverdlovskoj oblasti za 2018 g. / [Elektron. resurs]/ Elektron.dan. - Rezhim dostupa: https://sverdlovsk.roskazna.ru/upload/iblock/3ca/public hnyy-otchet.pdf (data obrashcheniya 25.03.2020).

[21] Publichnyj otchyot o rezul'tatah deyatel'nosti Upravleniya Federal'nogo kaznachejstva po Sverdlovskoj oblasti za 2019 g. [Elektronnyj resurs]/ Elektron.dan. $\quad-\quad$ Rezhim dostupa: https://sverdlovsk.roskazna.ru/upload/iblock/0fc/public hnyy-otcheto-rezultatakh-deyatelnosti-upravleniya.pdf (data obrashcheniya 25.03.2020).

[22] Prikaz Federal'nogo kaznachejstva ot 18.08.2017 N 206 "Ob organizacii rabot v prikladnom programmnom
[23] Prikaz Kaznachejstva Rossii ot 13.07.2018 N 199 (red. ot 24.08.2018) "Ob utverzhdenii Poryadka planirovaniya kontrol'nyh meropriyatij $\mathrm{v}$ finansovobyudzhetnoj sfere, provodimyh Federal'nym kaznachejstvom i upravleniyami Federal'nogo kaznachejstva po sub"ektam Rossijskoj Federacii, i priznanii utrativshimi silu nekotoryh prikazov Federal'nogo kaznachejstva" [Elektronnyj resurs]/ Konsul'tantPlyus -Rezhim dostupa: http://www.consultant.ru/document/cons_doc_LAW_3 06192/ (data obrashcheniya 26.03.2020).

[24] Prikaz Kaznachejstva Rossii ot 12.12.2016 N 460 "O vvode v ekspluataciyu prikladnogo programmnogo produkta "Avtomatizirovannaya sistema planirovaniya kontrol'noj i nadzornoj deyatel'nosti Federal'noj sluzhby finansovo-byudzhetnogo nadzora $\mathrm{v}$ ispolnyaemyh modulyah" [Elektron. resurs]/ Konsul'tantPlyus Rezhim dostupa: http://www.consultant.ru/cons/cgi/online.cgi?req=doc\& base $=E X P \& n=676442 \# 0966941322993909 \quad$ (data obrashcheniya 26.03.2020).

[25] "O vnedrenii sistem distancionnogo kontrolya $\mathrm{v}$ ramkah realizacii reformy kontrol'no-nadzornoj deyatel'nosti" [Elektron. resurs] - Rezhim dostupa: http://government.ru/news/38172/\#aleshin (data obrashcheniya 26.03.2020).

[26] Simko N.N. Kontrol' v finansovo-byudzhetnoj sfere // Konsul'tant Sverdlovskaya oblast'. No. 12. 2019. S. 2635 / Informaciya s oficial'nogo sajta Upravleniya Federal'nogo kaznachejstva po Sverdlovskoj oblasti [Elektronnyj resurs]/ - Elektron.dan. - Rezhim dostupa: https://sverdlovsk.roskazna.ru/inaya-

deyatelnost/publikacii/detail.php?id=1416765 (data obrashcheniya 26.03.2020).

[27] Postanovlenie Pravitel'stva RF ot 02.03.2019 N 234 (red. ot 07.12.2019) "O sisteme upravleniya realizaciej nacional'noj programmy "Cifrovaya ekonomika Rossijskoj Federacii" (vmeste s "Polozheniem o sisteme upravleniya realizaciej nacional'noj programmy "Cifrovaya ekonomika Rossijskoj Federacii") [Elektronnyj resurs]/ Konsul'tantPlyus - Elektron.dan. Rezhim dostupa: http://www.consultant.ru/document/cons_doc_LAW_3 19701/ (data obrashcheniya 27.03.2020).

[28] Simko N.N. Osobennosti primeneniya metodov finansovogo kontrolya $\mathrm{v}$ Rossijskoj praktike // Finansovaya ekonomika. 2020. No. 2. S. 213-216. 
[29] Artyuhin R.E. Rol' Federal'nogo kaznachejstva v obespechenii "proslezhivaemosti" hoda realizacii nacional'nyh proektov // Finansovaya bezopasnost'. Fevral'. 2020. No. 26. S. 6-9/ [Elektronnyj resurs]/ Elektron.dan. $\quad-\quad$ Rezhim dostupa: https://www.roskazna.ru/upload/iblock/db3/statya_ruko voditelya_federalnogo_kaznacheystva_r.e._artyukhina_ 1_9.pdf (data obrashcheniya 27.03.2020).

[30] Isaev E.A. Podhody $\mathrm{k}$ cifrovizacii kontrolya $\mathrm{v}$ finansovo-byudzhetnoj sfere (TEKST) // Byudzhet ot Kaznachejstva. 2019. S. 48-50 [Elektronnyj resurs]/ Elektron.dan. $\quad-\quad$ Rezhim dostupa: https://www.roskazna.ru/upload/iblock/81d/isaev_05_2 019.pdf (data obrashcheniya 27.03.2020).

[31] Rasshirennoe zasedanie Kollegii Federal'nogo kaznachejstva, sostoyavsheesya 18 marta $2020 \mathrm{~g}$. [Elektron. resurs]/ -Rezhim dostupa: https://www.roskazna.ru/novosti-isoobshheniya/novosti/1431611/ (daty obrashcheniya: 18.03.2020 i 27.03.2020).

[32] Jathan Sadowski. The Internet of Landlords: Digital Platforms and New Mechanisms of Rentier Capitalism. Antipode. Vol. 52 No. 2. 2020 ISSN 0066-4812, pp. 562-580 doi: 10.1111/anti.12595

[33] ANG Y.Y. Centralizing treasury management in China: the rationale of the central reformers. Public administration and development. Public Admin. Dev. 29, 263-273 (2009). DOI: 10.1002/pad.537

[34] Aleshin A.V. "O vnedrenii sistem distancionnogo kontrolya $\mathrm{V}$ ramkah realizacii reformy kontrol'nonadzornoj deyatel'nosti". - Mat-ly Federal'noj sluzhby po ekologicheskomu, tekhnologicheskomu i atomnomu nadzoru (Rostekhnadzora). - Ekaterinburg, 23 okt 2019 $\mathrm{g}$ 